\title{
READINESS FORMATION OF FUTURE ELEMENTARY SCHOOL TEACHERS TO INTERACT WITH PARTICIPANTS IN THE EDUCATIONAL PROCESS ON THE PARTNERSHIP PEDAGOGY BASIS
}

\author{
Tetiana Fedirchyk ${ }^{1}$, Vitaliia Didukh ${ }^{2}$ \\ ${ }^{I}$ Doctor of Pedagogical Sciences, Professor, Dean of the Faculty of Pedagogy, Psychology and Social Work, \\ at Yuriy Fedkovych Chernivtsi National University, Ukraine, e-mail: t.fedirchyk@chnu.edu.ua \\ ${ }^{2}$ Postgraduate the Department of Pedagogy and Methods of Elementary Education, at Yuriy Fedkovych \\ Chernivtsi National University, Ukraine, e-mail: didukh.vitalia@chnu.edu.ua
}

\begin{abstract}
The article studies the problem on forming the readiness of the future elementary school teachers to interact with participants in the educational process on the basis of partnership pedagogy in psychological and pedagogical science and modern educational practice. Participants during the interaction in the educational process are: teachers, students and their parents, educational managers, psychologists, social educators, as well as health professionals and others.

The pedagogy of partnership is grounded as a factor of effective interaction between participants of educational process and is opened as the certain system of mutual relations of all participants in educational process (teachers, pupils, parents, educational managers, etc.), which is based on principles: voluntariness, equality, democracy, respect to the person concerning the outlined norms (rules, requirements, responsibilities), each party values and provides for active cooperation in the common educational tasks implementation under each responsibility for the obtained results.
\end{abstract}

The essential, structural and semantic analysis of the concept "readiness of the future elementary school teachers to interact with the educational process participants» was carried out. The components of students' readiness as future teachers are defined as motivational, cognitive, operational and personal. The readiness levels of future primary school teachers to interact with the participants of the educational process on the basis of partnership pedagogy include: low (intuitive), medium (reproductive), sufficient (productive) and high (creative). The summative research results of the formation state of the future primary school teachers' readiness to implement the ideas of partnership pedagogy in cooperation with participants in the educational process are presented.

The formation model of the future elementary school teachers' readiness for interaction with participants of educational process on the partnership pedagogy basis is theoretically substantiated. The paper describes the pedagogical conditions for the implementation of this model, which include: creating a favourable educational environment for the formation of motives and focus on partnership in the pedagogical process; the content optimization of educational programs on mastering the essence, principles and ways of organizing cooperation on the partnership pedagogy basis; organization in the process of professional training of future teachers interaction in the system "teacher-student» as a model of effective interaction of participants in the educational process; the use of learner-centred technologies aimed at mastering the forms and methods of organizing partnerships; the students involvement into the partnerships implementation in the school educational environment during various types of practical training.

Keywords: primary school teacher, professional training, readiness of future elementary school teachers, pedagogical interaction, partnership, partnership pedagogy, educational process participants.

JEL Classification: I24, I29

Formulas: 0; fig.: 2; tabl.: 0; bibl.: 34

Introduction. Modernization and reform of education in Ukraine has led to values upheaval and changing the society strategy. Appropriately, the personality of the modern teacher there are put forward new requirements. In the context of 
reforming the elementary school of Ukraine, the primary school teacher must be competitive, should be able to adequately respond to the challenges of the time, to implement new educational standards based on the partnership pedagogy, innovation and axiology. Nowadays, the teacher must be ready to find effective forms and methods of interaction with participants in the educational process (teachers, students, parents, educational managers, etc.) on the basis of partnership pedagogy. The future teachers' professional training should be aimed at forming their readiness to perform these tasks.

Analysis of the state legal framework of education (Law of Ukraine «On Education» (2017) [28]; Law of Ukraine «On Higher Education» (2014) [27]; Concept «New Ukrainian School» (2016) [26]; Concept of education development in Ukraine period 2015-2025 (2015) [25]; State Standard of Primary General Education (2018) [24]) indicates the need to prepare primary school teachers to interact with participants in the educational process on the basis of partnership, which is based on child-centeredness.

Literature Review. The studied problem was considered by various scientists in the following aspects:

- theoretical and practical training features of future elementary school teachers $(\mathrm{O}$. Savchenko [20], V. Chaika [5], L. Onyshchuk [19], L. Khomych [14], N. Bibik [3], O. Bida [4], N. Nikula [10] and others);

- interpersonal interaction psychology in education (A. Dobrovych [8], G. Zuckerman [32], I. Zymnya [34], V. Zinchenko [31]);

- pedagogical interaction ideas and ways of its denelopment in educational process (Sh. Amonashvili [1], O. Kyrychuk [17], M. Kaminska [12], T. Bashynska [2], L. Velytchenko [29], A. Chernyavska [7], K. Sedih [21], O. Zhdanova-Nedilko [30], E. Linnik [18]).

In addition to a significant number of scientific works and proper development by scientists of various aspects on the problem, there is a lack of research that would integrally present the formation of future primary school teachers to interact with participants in the educational process on the partnership pedagogy basis in training the New Ukrainian School Concepts.

Aims. The aim of the article is to analyse the problem of future primary school teachers readiness to interact with participants in the educational process on the basis of partnership pedagogy in psychological and pedagogical science and modern educational practice; theoretical development of the formation model on the readiness of future elementary school teachers to interact with participants of the educational process on the partnership pedagogy basis.

Methods. The research was carried out using a set of scientific methods as follows: theoretical methods (comparative and historical analysis, systematization and the scientific literature analysis (philosophical, psychological, and pedagogical), legislative, regulatory documents, empirical methods (testing, questionnaires, and surveys), mathematical methods of processing results, graphical methods for highlighting the results in the form of tables, diagrams. 
In order to determine the readiness level of future elementary school teachers to interact with the participants of the educational process on the partnership pedagogy basis, we used a set of methods that are:

- professionally significant qualities were measured using the methods of COS V. Sinyavskyi and B. Fedoryshyn «Assessment of communicative and organizational skills», allowed to determine communicative and organizational qualities, purposefulness, ability to understand each other [23];

- readiness to implement the principles of the «New Ukrainian School» Concept was determined by testing «Are you ready for the New Ukrainian School» developed by O. Simonchuk [22];

- ability to reflection and self-development we determined using the method of A. Karpov «Diagnosis of reflection» [13] and test by D. Leontiev «Differential type of reflection» which allowed to identify the level of pedagogical reflection and its type, the ability of future primary school teachers to self-assessment, self-knowledge, to identify skills of self-correction and readiness for self-education and selfdevelopment [16].

Results. Theoretical analysis of the «partnership pedagogy» concept suggests that it is multifaceted. We believe that the most comprehensive and holistic interpretation of this scientific concept is the definition of N. Bibik, where the author points out that the pedagogy of partnership is based on the principles of voluntariness, equality, democracy, respect to the individual (rules, requirements, responsibilities) values of each party and provides for active cooperation in the implementation of common educational objectives under the responsibility of each for the results obtained. The aim of partnership pedagogy is to create a new humane society, free from totalitarianism and built on democracy principles. The main task of partnership pedagogy is to overcome the passivity of thinking, the transition to a qualitatively new level of building relationships between participants in the educational process. This task is realized in the joint activities of teachers and students, parents, which involves mutual understanding, interests' unity and aspirations for the personal development of students [3, p. 16 ].

The New Ukrainian School Concept stipulates that partnership pedagogy is based on the following defining principles: respect for the individual; friendliness and positive attitude; trust in relationships; the principle «dialogue - interaction - mutual»; distributed leadership (proactivity, the right to choose and responsibility for it, the horizontality of connections); social partnership (parties equality, voluntary commitment, mandatory implementation of agreements) [26, p. 14 ].

Examining the scientific and pedagogical literature, we found that the basis of pedagogical interaction is not only the relationship between teacher, student and parent, but also other participants in the educational process, which are directly related to the pedagogical interaction. We have identified the following participants in the educational process, namely: teachers, students and their parents, educational managers, psychologists, social educators, and health professionals. 
Based on the theoretical analysis of scientists' researches, it was found that the readiness of future elementary school teachers to interact with participants in the educational process is considered in relation to:

- understanding it through other psychological and pedagogical concepts [6];

- regarding the essence of professional activity [11];

- systems of professional self-development [33].

Thus, scientists interpret differently the semantic content of the «readiness» concept.

A. Linenko, points out that the readiness for pedagogical activity is a holistic stable formation, characterized by emotional and cognitive, volitional and operational mobilization of the subject at the time of its inclusion in the activity. As readiness components for the work of the teacher, the author considers professional selfconsciousness, the relation to activity, its motives, subject knowledge and ways of activity, skills and abilities of their practical embodiment, professionally significant qualities. A. Linenko attaches great importance to pedagogical self-awareness, which is necessary for the active regulation of professional activity. Understanding yourself as a teacher, your aspirations, opportunities, the availability of adequate selfassessment of their own pedagogical abilities, suitability for teaching, all this is a necessary prerequisite for the professional formation of future educators [17].

Thus, the analysis of the concept of «readiness» suggests that the readiness of future primary school teachers to professional activities is considered by scientists as a certain formation of personal character, which is characterized by the presence of future professional internal motives, pedagogical abilities, knowledge, skills and skills, professionally significant personality traits. Scientists also consider the procedural side of readiness, covering both knowledge of the subject and methods of activity.

Thus, the readiness of primary school teachers to interact with participants in the educational process means a holistic integrative set of motives and professional orientation of the individual, professional competencies, professionally significant qualities and ability to reflect and personal-professional self-development.

In the content of the readiness of future elementary school teachers to interact with the participants of the educational process, it is necessary to take into account both activity and psychological components. Therefore, the consideration of readiness in research is fulfilled in two main aspects: functional and personal. According to the first, readiness is understood as a set of certain knowledge necessary for the effective implementation of certain activities and skills formed on this basis and means of their successful inclusion in this activity. Within the second (personal aspect) readiness is interpreted as a complex integrative quality of personality, the structure of which consists of a number of components (motivational, cognitive, operational and personal).

Both components of the problem are essential for our study. They allow determining the content and structure of readiness of future primary school teachers to interact with participants in the educational process on the partnership pedagogy basis, where we can correlate the concept of «teacher's readiness to interact with 
participants in the educational process» with the concept of «partnership pedagogy». Based on this, we identified the components of readiness to interact with participants in the educational process on the partnership pedagogy basis, that is:

- motivational component, which provides for the formation of professional values, which awakens in future teachers a responsible attitude to teaching and professional activities; motives that motivate the acquisition of professional competencies; professional orientation on a positive model of pedagogical interaction, which serves as a guide in professional self-development;

- cognitive component involves the professional competence formation, which combines the formation of theoretical knowledge about the features, principles, laws and methods of partnership pedagogical interaction;

- operational component, which involves the possession of methods and techniques, necessary skills and abilities to establish partnerships with their application in practice;

- personal component involves the formation of professionally significant qualities that give the professional activity of the future primary school teacher expressed personal character, created on the partnership pedagogy principles.

Analysing the scientific and pedagogical literature, the «New Ukrainian School» Concept, in accordance with the professional competence of future elementary school teachers, we highlight the following criteria for the readiness of elementary school teachers to interact with participants in the educational process on the partnership pedagogy basis:

- awareness of the need to master the theoretical knowledge and methodological tools of effective partnership (motivational component);

- professional psychological and pedagogical knowledge about pedagogical interaction on the partnership pedagogy basis (cognitive component);

- professional and pedagogical skills in the field of implementation on the professional activity model of a primary school teacher on the basis of partnership pedagogy (operational component);

- professionally significant qualities of the teacher, which is important in the cooperation with the participants of the educational process (personal component).

Based on the components and criteria of readiness to interact with participants in the educational process on the partnership pedagogy basis, we determined the readiness levels of future elementary school teachers to interact with participants in the educational process on the partnership pedagogy basis, namely:

- low (intuitive) level. This level is characterized by insufficiently formed in students of professionally significant qualities, knowledge and skills and, as a consequence i.e. the inability to organize their activities, use time wisely, choose the appropriate style of communication in the process of pedagogical interaction. Representatives of this level are not creative in implementing the principles of the «New Ukrainian School» Concept, in particular the principles of partnership pedagogy; they do not work on their own mistakes and do not seek the selfdevelopment; 
- average (reproductive) level. It is characterized by the formation of students' professionally significant qualities, knowledge and skills of the future teacher to organize pedagogical interaction on the partnership basis, which are reproductive in nature, they have no elements of novelty, but rather elements of imitation of creativity (copying someone's creative ideas). At this stage, some of one's own mistakes are realized, which are not always recognized by the individual, due to which there is a wrong movement towards self-development and self-improvement;

- sufficient (productive) level. At this level, future primary school teachers have already formed professionally significant qualities, knowledge and skills, as well as the ability to reflect and self-knowledge in order to organize a partnership pedagogical interaction; they are able to evaluate the best practices of pedagogical interaction, but need help to use it; are able to develop a system of self-development and self-education;

- high (creative) level. This level is characterized by students' mastery of the knowledge and skills system, pedagogical techniques, ability to manage the emotional and volitional sphere during pedagogical interaction. Professionally significant qualities are manifested at a high level and promote creativity in the organization of partner pedagogical activities. Reflection at this level is formed quite highly, and is characterized by awareness of gaps in their own knowledge and skills, the desire to fill them, to prevent possible errors. The ability of critical selfknowledge is formed, and as a result there is creation and realization of the selfeducation, self-improvement, self-development creative plan.

We conducted an ascertaining study, the purpose of which was to determine the level of readiness of future primary school teachers to interact with participants in the educational process on the partnership pedagogy basis.

Yuriy Fedkovych Chernivtsi National University, Department of Pedagogy and Methods of Primary Education, was chosen as the basis for the empirical study. Respondents in the process of ascertaining research were students of 4-6 courses, full-time and part-time students in the specialty «Primary Education» in the amount of 140 people who according to the curriculum have mastered most of the theoretical and practical material and passed the main types of training practices.

Establishing appropriateness with the levels of readiness of future primary school teachers to interact with participants in the educational process was conducted on a scale generalized by us from 0 to 100 points. Based on this, our rating scale is distributed as follows: high (creative) level is 76-100 points; sufficient (productive) level is 51-75 points; average (reproductive) level is 26-50 points; low (intuitive) level is $0-25$ points.

To verify the selected scale, future educators were interviewed using the methods (tests) described above. The analysis of the results of the readiness level of future primary school teachers to interact with the participants of the educational process on the partnership pedagogy basis is presented in Figure 1.

Thus, the motivational component in $25 \%$ of respondents is formed at a high (creative) level; $24 \%$ of future primary school teachers are characterized by a sufficient (productive) level of this component formation; the average (reproductive) 
level is typical for $37.5 \%$ of students and $13.5 \%$ of respondents belong to the low (intuitive) level.

The cognitive component of the future primary school teachers readiness to interact with participants in the educational process on the partnership pedagogy basis at a high (creative) level is formed in $26.5 \%$ of respondents, and $21 \%$ at a sufficient (productive) level, middle (reproductive) level is typical for $42.5 \%$ of students, low (intuitive) level included $10 \%$.

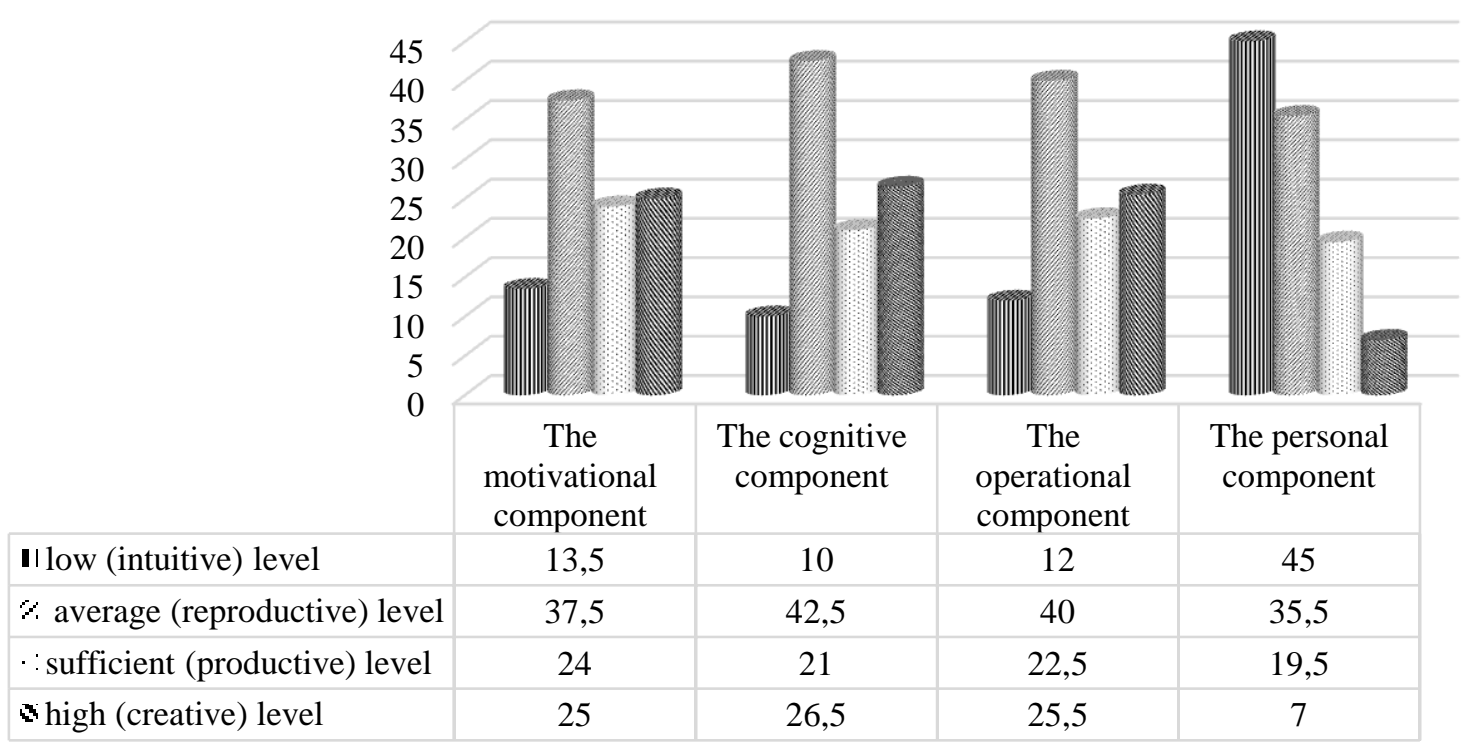

Fig.1. The readiness level of future elementary school teachers to interact with participants in the educational process on the partnership pedagogy basis

The operational component is formed at a high (creative) level in $25.5 \%$ of respondents, $22.5 \%$ of respondents belong to a sufficient (productive) level, $40 \%$ of future teachers have a medium (reproductive level), low (intuitive) level in $12 \%$.

The personal component of $7 \%$ of respondents is formed at a high (creative) level, and $19.5 \%$ is at a sufficiently (productive) level, the average (reproductive) level is characteristic of $35.5 \%$ of students and $45 \%$ of future teachers are low (intuitive) level.

Discussion. Thus, the results of determining the level of readiness of future primary school teachers to interact with participants in the educational process on the basis of partnership pedagogy showed the insufficient level of its formation and the feasibility of developing and implementing in the educational process a model of future primary school teachers' readiness to interact with pedagogical participants partnerships at the stage of their professional training (see Fig. 2).

The purpose of the model is to effectively form the readiness of future elementary school teachers to interact with participants in the educational process on the basis of partnership pedagogy in the training process.

The methodological block includes: principles of voluntariness, equality, democracy, respect for the individual according the outlined norms (rules, requirements, responsibilities), values of each party and involves active cooperation in the implementation of common educational tasks under the responsibility of each 
for the results. Also, this block of the model includes scientific approaches as personal and activity, competence, axiological, systemic, and components of readiness of future elementary school teachers to interact with participants in the educational process on the basis of partnership pedagogy: motivational, cognitive, operational, personal.

The technological block includes the content that supplements the topics of lecture seminars and practical professional and oriented disciplines with the content of issues aimed at forming readiness to interact with participants in the educational process on the basis of partnership pedagogy and implementation of elective courses «Partnership Pedagogy» and «Psychological and pedagogical foundations of partnership interaction in the educational process». Effective forms include: lecturesworkshops, lectures-trainings, discussions, debates, practical classes, trainings, webinars and master classes and methods: conversations, creative exercises, didactic games, designing, work on the decision of pedagogical situations, development and carrying out of exercises on the development of interaction. The effectiveness of the model of the readiness formation of future teachers to interact with the participants of the educational process on the basis of partnership pedagogy will be ensured through the implementation of pedagogical conditions:

- creating a favourable educational environment for the formation of motives and focus on partnership in the pedagogical process;

- optimizing the content of educational programs on mastering the essence, principles and ways of organizing interaction on the partnership pedagogy basis;

- organizing the process of professional training of future teachers of cooperation in the system «teacher-student» as a model of effective interaction of participants in the educational process;

- using the personality-oriented technologies aimed at mastering the forms and methods of partnership;

- involving of students in the implementation of partnerships in the educational environment of the school in the process of various types of practical training.

The effective block includes criteria (awareness of the need to master the theoretical knowledge and methodological tools of effective partnership; professional psychological and pedagogical knowledge of pedagogical interaction on the partnership pedagogy basis; professional and pedagogical skills in fulfilling the model of professional activity of the elementary school teachers on the partnership pedagogy basis; significant qualities of the teacher, which is important in interaction with participants in the educational process) and levels (low (intuitive), medium (reproductive), sufficient (productive), high (creative)) readiness of future primary school teachers to interact with participants in the educational process on the pedagogy partnerships basis.

Based on the model of forming the readiness of future primary school teachers to interact with participants in the educational process on the partnership pedagogy basis, we believe that this process consists of stages, which implementation involves the use of effective forms and methods. 
PURPOSE: to form the readiness of future elementary school teachers to interact with participants of the educational process on the partnership pedagogy basis
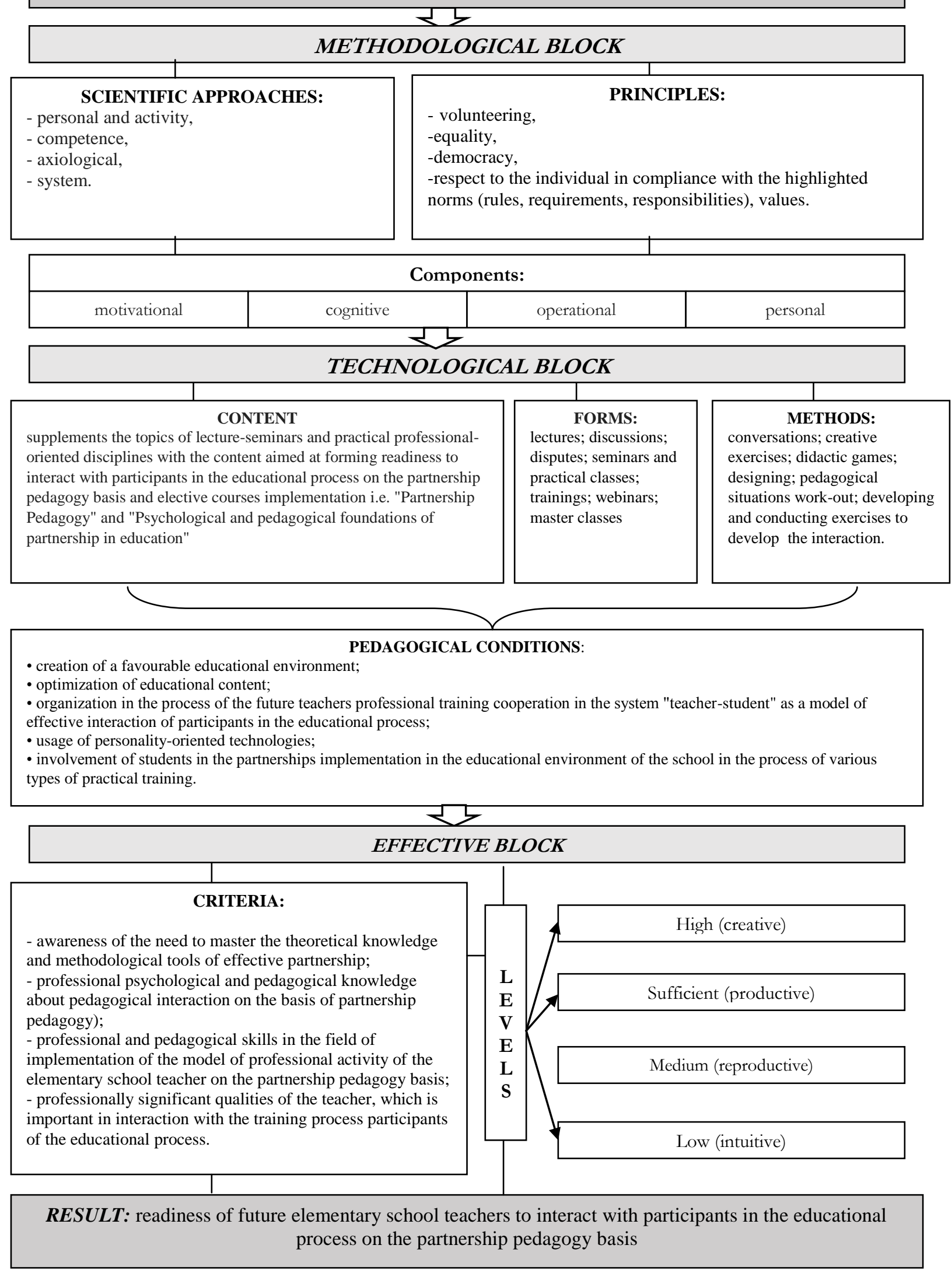

\section{Fig. 2. Model of readiness formation of future elementary school teachers for interaction with participants of the educational process on the pedagogy of partnership basis}


In particular, the first stage is the informational purpose that is to study and determine the essence of interaction, partnership, basic principles, and existing programs aimed at developing of interaction between participants in the educational process. At this stage, it is advisable to use such forms of work as information and practical round tables, lectures, seminars or conferences.

The second stage is modelling, the purpose of which is to define a clear model which is aimed at forming the readiness of future teachers to interact with participants in the educational process. It is expedient to implement the second stage through the prism of such forms of work as discussions, debates, methodical seminars, group and individual consultations.

At the third, practical stage, this model is implemented, directly, in practice, during the educational and practical training of applicants for higher education. We consider it appropriate to use such forms of work as methodical seminars, master classes, and trainings.

The fourth stage is evaluative and effective, the main task at this stage is not only to determine the effectiveness of the creating model the readiness of future elementary school teachers to interact with participants in the educational process, but also to develop prospects and recommendations to improve this model. The main forms of scientific and methodological support at this stage are conferences, round tables, colloquia.

Thus, in the fulfilment of these stages and forms of scientific and methodological support, we will be able to form the readiness of future elementary school teachers to interact with participants in the educational process on the basis of partnership pedagogy.

Conclusions. Thus, the partnership pedagogy acts as a factor of effective interaction between participants in the educational process, which provides the main goal of the «New Ukrainian School» Concept, which is to support students, meet the intellectual, emotional and social needs of the child. Analysing the results of the observational study, we found that in order to effectively form the readiness of future primary school teachers to interact with participants in the educational process on the basis of partnership pedagogy, it is advisable to improve their professional training, which is our proposed model. Prospects for further scientific research are related to testing the model effectiveness of forming the readiness of future elementary school teachers to interact with participants in the educational process and the development of scientific and methodological support of this process.

Author contributions. The authors contributed equally.

Disclosure statement. The authors do not have any conflict of interest. References:

1. Amonashvili, Sh. A. (1996). Reflections on humane pedagogy [in Russian].

2. Bashynska, T. P. (2004). Interaction of teachers and students in the educational process as a pedagogical problem. Elementary School., 12, 55-58 [in Ukrainian].

3. Bibik, N. M. (2017). New Ukrainian school: a guide for teachers. Kyiv: Publishing House [in Ukrainian].

4. Bida, O. A., Goncharuk, V. V., Goncharuk, V. A. (2019). Professional mobility as a factor in the professional success of a modern specialist. Scientific notes of Volodymyr Vynnychenko the Central Ukrainian State Pedagogical University, 178, 17-121 [in Ukrainian].

5. Chaika, V.M. (2006). Preparation of the future teacher for self-regulation of pedagogical activity. Ternopil: TNPU. The Way of Education, 2 (20), 15-19 [in Ukrainian]. 
6. Chepelyeva, N. V. (1989). Psychological culture of the future teacher. K .: Knowledge [in Ukrainian].

7. Chernyavskaya, A. P. (2007). Partner position as the basis for the organization of subject-subject interaction in school. Yaroslavl Pedagogical Bulletin., 3, 3-8 [in Ukrainian].

8. Dobrovych, A. B. (1987). To the preschool teacher about psychology and psycho-hygiene of communication. M .: Prosveshcheniye [Moscow].

9. Durai-Novakova, K. M. (1983) The professional readiness formation of students on pedagogical activity (Author's dissertation on the doctor of pedagogical sciences) [in Russian].

10. Fedirchyk, T., Nikula, N. (2019). Formation of Methodology Culture of Would-be Elementary School Teachers in the Context of Introduction of "New Ukrainian School". Revista Romaneasca pentru Educatie Multidimensionala, 11 (1), 41-56. URL: https://doi.org/10.18662/rrem/95 [in Romania].

11. Garkusha, S. V. (2003). Concepts and components of professional readiness of future teachers for professional activity. sBulletin of Chernihiv National Pedagogical University. Pedagogical Sciences, 110, 198-201 [in Ukrainian].

12. Kaminska, M. V. (2003). Pedagogical dialogue in the activity of a modern teacher. M .: Smysl [in Russian].

13. Karpov, A. V. (2003). Reflexivity as a mental property and methods of its diagnosis. Psychological Journal, 24 (5), 45-57 [in Ukrainian].

14. Khomich, L. O. (2010). Axiological approach is the basis for the formation of a holistic personality of the future teacher. Kyiv - Nizhyn: PP Lysenko M [in Ukrainian].

15. Kyrychuk, O. V. (1997). Dialogue in the context of pedagogical interaction. K: IZMN [in Ukrainian].

16. Leontyev, D. A., Osin, E. M. (2014) Reflection "good" and "bad": from an explanatory model to differential diagnosis. Psychology. Magazine. 4, 110-135. [in Ukrainian].

17. Linenko, A. F. (1996) Theory and practice of readiness formation of students of pedagogical high schools for professional activity. (Author's dissertation. Doctor of Pedagogical Sciences). Institute of Pedagogy and Psychology of Vocational Education of the Academy of Pedagogical Sciences of Ukraine [in Ukrainian].

18. Linnik, E. P. (2015). Pedagogical interaction: subject-subject approach: Preparation of the future elementary school teacher for the organization of subject-subject interaction with students [in Ukrainian].

19. Onyshchuk, L. A. (2008). The essence and content of professional competence of the future teacher. Pedagogical education and adult education: the European dimension: Coll. Science. pr., 455-463 [in Ukrainian].

20. Savchenko, O. Ya. (2001). Improving the professional training of future elementary school teachers. Elementary School, 7, 1-4 [in Ukrainian].

21. Sedih, K. W. (2008). Psychology of systems interaction: "family and educational institutions". Poltava: Dovkilya [in Ukrainian].

22. Simonchuk, O. V. (2018). Test "Are you ready for the New Ukrainian School?" URL: https://osvitoria.media/experience/test-chy-gotovi-vy-do-nush/

23. Sinyavskyi, V. A, Fedoryshyn, V.A. (2009). Communicative and organizational tendencies: the text of the questionnaire. Library. URL: http://testoteka.narod.ru/lichn/1/17.html [in Ukrainian]/

24. State standard of elementary general education (2018). URL: https://www.kmu.gov.ua/npas/pro-zatverdzhennyaderzhavnogo-standartu-pochatkovoyi-osviti

25.The concept of education development in Ukraine during the period 2015-2025 URL: http://tnpu.edu.ua/EKTS/proekt_koncepc.pdf

26. The New Ukrainian School concept (2016). URL: https://mon.gov.ua/storage/app/media/zagalna\%20serednya/novaukrainska-shkola-compressed.pdf

27. Ukraine. Verkhovna Rada. Law (2014). On higher education. (2014). URL: http://zakon2.rada.gov.ua/laws/show/1556-18

28. Ukraine. Verkhovna Rada. Law (2017). On education. URL: http://zakon3.rada.gov.ua/laws/show/2145-19

29. Velytchenko, L. K. (2006). Psychological bases of pedagogical interaction. (Author's dissertation on Dr. of Psychological Sciences) Kyiv [in Ukrainian].

30. Zhdanova-Nedilko, O. G. (2014). Interaction as a key concept of the pedagogical process. Origins of pedagogical skill, 13, 128-133 [in Ukrainian].

31.Zinchenko, V. P (2004). Thinking and language. Dubna [in Ukrainian].

32.Zuckerman, G. A. (1995). Psychology of self-development. M .: Interprax [in Russian].

33. Zyazyun, I. A. (2011). New technologies of training teachers in Ukraine. Scientific Bulletin of V.O. Sukhomlynsky Mykolayiv State University. Pedagogical Sciences, 1.32, 16-21 [in Ukrainian].

34. Zymnyaya, I. A .(2000). Pedagogical psychology. M .: Izd. Logos Corporation [in Russian]. 